Takayuki Komatsubara MD, Yuji Kadoi MD, Shigeru Saito MD

\title{
Augmented sensitivity to benzodiazepine in septic shock rats
}

The purpose of this study was to assess the pharmacological characteristics of the benzodiazepine binding site in the brain of septic animals. We induced endotoxin shock in rats using a caecum ligation and puncture model. Following examination of the physiological state of the rats $24 \mathrm{hr}$ after the caecum ligation and puncture, brain tissue samples were prepared for biochemical assay of amino acids and for the $\left[{ }^{3} \mathrm{H}\right]$-diazepam radioligand binding assay. Amino acids assays indicated that the concentration of aromatic amino acids was higher in the CLP group $(P<0.05)$, the branched chain amino acid concentration was lower in the CLP group $(P<0.05)$ and the sulfur-containing amino acid concentration was elevated in the CLP group $(P<0.05)$ than in both the control and the shamoperated groups. $\left[{ }^{3} \mathrm{H}\right]$-diazepam radioligand binding assays demonstrated that the number of receptors in the septic rats was increased in the forebrain (CLP rats; $2.37 \pm 0.04$ pmol $\cdot \mathrm{mg}^{-1}$ protein, control rats; $1.45 \pm 0.02 \mathrm{pmol} \cdot \mathrm{mg}^{-1}$ protein, sham-operated rats; $1.49 \pm 0.03 \mathrm{pmol} \cdot \mathrm{mg}^{-1}$ protein), cerebellum (CLP rats; $1.55 \pm 0.05 \mathrm{pmol} \cdot \mathrm{mg}^{-1}$ protein, control rats; $1.05 \pm 0.02 \mathrm{pmol} \cdot \mathrm{mg}^{-1}$ protein, sham-operated rats; 1.09 $\pm 0.02 \mathrm{pmol} \cdot \mathrm{mg}^{-1}$ protein) and brain stem (CLP rats; 1.21 $\pm 0.04 \mathrm{pmol} \cdot \mathrm{mg}^{-1}$ protein, control rats; $0.61 \pm 0.02$ $\mathrm{pmol} \cdot \mathrm{mg}^{-1}$ protein, sham-operated rats; $0.63 \pm 0.02$ $\mathrm{pmol} \cdot \mathrm{mg}^{-1}$ protein) compared with the control and shamoperated rats $(P<0.05)$. In conclusion, it was considered that the increased number of benzodiazepine receptors may be one cause of the neuronal alteration observed in septic shock animals.

\section{Key words}

COMPLICATIONS: shock;

INFECTION: septicaemia;

HYPNOTICS: benzodiazepine.

From the Department of Anesthesiology and Reanimatology, Gunma University School of Medicine, 3-39-22, Showa-machi, Maebashi, 371, Japan.

Address correspondence to: Dr. Shigeru Saito, Department of Anesthesiology and Reanimatology, Gunma University School of Medicine, 3-39-22, Showa-machi, Maebashi, 371, Japan.

Accepted for publication 26th May, 1995.
L'objectif de cette étude était d'évaluer chez des animaux septiques les caractéristiques pharmacologiques des récepteurs cérébraux des benzodiazépines. Les auteurs ont provoqué un choc septique en conformité avec un modèle de ligature et de perforation du caecum chez le rat. Après l'examen de l'état physiologique des rats 24 heures après la ligature du caecum et sa perforation, des échantillons de tissus cérébral ont été préparés pour une analyse biochimique des acides aminés et l'épreuve de liaison au radioligant $\left[{ }^{3} \mathrm{H}\right]$-diazepam. Les épreuves de mesure des acides aminés ont montré que la concentration des acides aminés aromatiques était plus élevée dans le groupe $C L P(P<0,05)$, que la concentration des acides aminés à chaîne ramifiée était plus basse dans le groupe $C L P(P<0,05)$ et que la concentration des acides aminés sulfurés était plus élevée dans le groupe CLP comparativement au groupe contrôle et au groupe interventions factices. Les épreuves de liaison au radioligand $\left[{ }^{3} \mathrm{H}\right]$-diazépam ont montré que le nombre de récepteurs chez les rats septiques était augmenté dans le proencéphale (rats CLP; 2,37 $\pm 0,04 \mathrm{pmol} \cdot \mathrm{mg}^{-1}$ de protéines, rats contrôles; $1,45 \pm 0,02 \mathrm{pmol} \cdot \mathrm{mg}^{-1}$ de protéine, les rats opérés de façon factice; $1,49 \pm 0,03 \mathrm{pmol} \cdot \mathrm{mg}^{-1}$ de protéine) dans le cervelet (rats CLP; 1,55 $\pm 0,05 \mathrm{pmol} \cdot \mathrm{mg}^{-1}$ de protéine, rats contrôles; $1,05 \pm 0,02 \mathrm{pmol} \cdot \mathrm{mg}^{-1}$ de protéine, les rats opérés de façon factice; $1,09 \pm 0,02 \mathrm{pmol} \cdot \mathrm{mg}^{-1}$ de protéine) et dans le bulbe (rats CLP; $1,21 \pm 0,04 \mathrm{pmol} \cdot \mathrm{mg}^{-1}$ de protéine, rats contrôles; $0,61 \pm 0,02 \mathrm{pmol} \cdot \mathrm{mg}^{-1}$ de protéine; rats opérés de façon factice; $0,63 \pm 0,02 \mathrm{pmol} \cdot \mathrm{mg}^{-1}$ de protéine) comparativement aux contrôles et aux rats opérés de façon factice $(P<0,05)$. Pour conclure, les auteurs considèrent que l'augmentation des récepteurs des benzodiazepines pourrait être une cause de l'altération neurale observées chez les animaux en choc septique.

Benzodiazepines have been widely used in clinical practice for more than $30 \mathrm{yr}$, as a sedative, anticonvulsant or as a subsidiary anaesthetic agent in neuroleptanaesthesia. ${ }^{1}$ Although unfavourable side effects, such as memory disorder and slight cardiovascular depression, have been reported, these drugs are prescribed even to critically ill patients, in whom special precautions are taken by cardiopulmonary monitoring. ${ }^{2}$ Patients suffering from sepsis often manifest dysfunction of the central nervous system (CNS), showing symptoms such as agitation, irritability, 
confusion, somnolence, disorientation, obtundation, stupor, and even coma. ${ }^{3,4}$ Although the precise molecular mechanism of these symptoms is not yet fully understood, several investigators have described neurophysiological and neurobiochemical alterations in the central nervous system of septic patients and of septic animal models. ${ }^{5,6}$ As biochemical alterations occur in the central nervous system during sepsis, it is possible that the pharmacological action of a neuroactive substance such as benzodiazepine is modified in such conditions. The plasma amino acid pattern is altered in septic encephalopathy patients, and this change in the plasma amino acid pattern resembles that found in patients with hepatic encephalopathy. ${ }^{7}$ Furthermore, Baraldi et al. reported that benzodiazepine receptors were increased in mild and severe hepatic encephalopathy, symptoms of which are similar to those observed in septic encephalopathy. ${ }^{8}$ To determine whether the benzodiazepine receptors are increased during severe sepsis, we studied the benzodiazepine receptor density using the caecum ligation and puncture animal model.

\section{Methods}

This study was performed in accordance with the ethical principles provided by the Japanese Ministry of Science and Education and the Experimental Animal Laboratory of Gunma University School of Medicine. All assays were performed with randomization and masking of samples.

\section{Models of experimental sepsis}

Male Wister rats (seven weeks, $180-250 \mathrm{~g}$ body weight) were used in all experiments. Eighteen rats were divided into three groups for systemic physiological and biochemical measurements; (1) control group $(n=6)$, (2) shamoperated group $(n=6)$, (3) caecal ligation and puncture (CLP) group $(n=6)$. The caecal ligation and puncture (CLP) model of sepsis was produced using the technique described and characterized by Wichterman et al. ${ }^{9}$ Under light ether anaesthesia, a $2 \mathrm{~cm}$ midline incision was made and the caecum was carefully exposed avoiding all blood vessels. The caecum was ligated just below the ileocecal valve with a 3-0 silk ligature. The antimesenteric caecal surface was punctured twice with an 18-gauge needle and a small amount of the caecal contents was expressed. The bowel was returned to the peritoneal cavity and the abdomen was closed in two layers with 3-0 silk. In the sham-operated groups, ligation and puncture of the caecum were omitted. The operated rats, including the shamoperated rats, received subcutaneous saline $(10 \mathrm{ml})$ and were kept in cages with access to food and water ad lib. This experimental caecal ligation and puncture (CLP) model resulted in approximately $20 \%$ mortality at $24 \mathrm{hr}$ after the surgical procedure.
The rats were cannulated with a 24-gauge teflon catheter through the femoral artery to examine heart rate and blood pressure and to collect blood samples. At 24 $\mathrm{hr}$ after the operation, blood pressure and heart rate were measured using an arterial blood pressure monitoring system (AP-601G; Nihon Koden, Japan) connected to the femoral artery catheter. (A teflon catheter was cannulated one hour prior to monitoring.)

Arterial blood gas analysis, the plasma epinephrine and norepinephrine concentrations, and plasma glucose concentration were determined $24 \mathrm{hr}$ after the treatment using blood samples obtained under room air conditions. Arterial blood gases were analyzed using an acid-base laboratory machine (ABL3, Radiometer, Copenhagen, Denmark). The plasma epinephrine and norepinephrine concentrations were measured by the column switching post labelling method ${ }^{10,11}$ using an automatic catecholamine analyzer (HLC-8030; Toso Co. Ltd., Japan) (sensitivity: $0.01 \mathrm{ng} \cdot \mathrm{ml}^{-1}$; coefficients of variation: $1.0 \%$ ). The plasma glucose was measured using an automatic assay system (Antense ${ }^{\circledR}$; Daikin Co. Ltd., Japan).

In addition, the plasma endotoxin and plasma amino acid concentrations were measured $24 \mathrm{hr}$ after treatment. The plasma endotoxin concentration was measured by a new endotoxin-specific chromogenic test ${ }^{12,13}$ (Endospecy test; Seikagaku Co. Ltd., Japan) (sensitivity: 0.1 $\mathrm{pg} \cdot \mathrm{ml}^{-1}$; coefficients of variation: $0.32 \%$ ). The concentration of plasma amino acids was measured by automated pre-column O-phthaldialdehide derivatization high performance liquid chromatography ${ }^{14,15}$ using a high speed amino acid analyzer (L-8500; Hitachi, Japan) (sensitivity: $1.0 \mathrm{nM} \cdot \mathrm{ml}^{-1}$; coefficients of variation: $0.5 \%$ ).

For neurobiochemical measurements, another set of animals (24 Wister rats) representing the same group of control $(n=8)$, sham-operated $(n=8)$ and the caecal ligation and puncture (CLP) rats $(n=8)$ were prepared as described as above. At $24 \mathrm{hr}$ after the surgical procedure the animals were sacrificed by decapitation. The brain was excised as rapidly as possible, and the forebrain, cerebellum, and brain stem were dissected as previously described. ${ }^{16}$ The samples were frozen on dry ice and stored at $-80^{\circ} \mathrm{C}$. All rats used for biochemical measurements were survivors of the experimental protocols.

\section{Membrane preparation for benzodiazepine receptor assay}

Preparation of synaptosomal membranes was carried out as described by Möhler and Okada with minor modifications. ${ }^{17}$ Briefly, the frozen samples were thawed and homogenized in $10 \mathrm{vol}$. of $0.32 \mathrm{M}$ sucrose, using a Potter homogenizer. The homogenate was centrifuged at 1000 $\mathrm{g}$ for ten minutes at $4^{\circ} \mathrm{C}$, and the supernatant was recentrifuged at $11500 \mathrm{~g}$ for $20 \mathrm{~min}$ at $4^{\circ} \mathrm{C}$. The pellet 
was suspended in ice-cold $50 \mathrm{mM}$ Tris- $\mathrm{HCl}(\mathrm{pH} 7.4)$, $10 \mathrm{mM} \mathrm{MgCl}$ buffer. This suspension was centrifuged and washed twice in the same buffer. The final pellet was resuspended in $50 \mathrm{mM}$ Tris buffer to yield a synaptosomal membrane suspension with a protein concentration of $2-3 \mathrm{mg} \cdot \mathrm{ml}^{-1}$. The protein concentration was determined by the Bradford method using gammaglobulin as a standard. ${ }^{18}$

\section{Benzodiazepine receptor binding}

The benzodiazepine receptor binding was assayed as described by Zeneroli et al. with minor modifications. ${ }^{19}$ In order to remove endogenous inhibitory materials, the membranes were resuspended, extensively washed and pelleted by centrifugation in $50 \mathrm{mM}$ Tris- $\mathrm{HCl}, 50 \mathrm{mM}$ $\mathrm{KCl}\left(\mathrm{pH} \mathrm{7.1)}\right.$ after incubation at $37^{\circ} \mathrm{C}$ for $30 \mathrm{~min}$. After the final wash, the pellets were resuspended in $50 \mathrm{mM}$ Tris- $\mathrm{HCl}$ (pH 7.1) buffer. An aliquot of membrane solution was incubated in a final volume of $1 \mathrm{ml}$ containing $50 \mathrm{mM}$ Tris- $\mathrm{HCl}(\mathrm{pH} 7.1)$ buffer and $\left[{ }^{3} \mathrm{H}\right]$-diazepam (NEN Research Products, Boston MA). Non-specific binding was determined in the presence of $1 \mu \mathrm{M}$ diazepam (Hoffmann-La Roche, Japan). After a $20 \mathrm{~min}$ incubation, the samples were rapidly filtered through Whatman GF/C filters under reduced pressure. The filters were immediately placed in scintilation vials and dried at $100^{\circ} \mathrm{C}$ for $60 \mathrm{~min}$, then $3 \mathrm{~m}$ of the scintilation cocktail (Reaflor ${ }^{\circledR}$, Sigma Chemical Co. Ltd., St Louis, MO) was added. The radioactivity trapped on the filters was measured using a liquid scintilation counter (Aloca 650; Aloca Co. Ltd., Japan).

\section{Binding assay data analysis}

The specific binding of $\left[{ }^{3} \mathrm{H}\right]$-diazepam was calculated by subtracting the value for the non specific binding determined in the presence of an excess of an unlabelled ligand from the value for total binding. Using Scatchard analysis, we demonstrated that the binding characteristics of diazepam were typical of a single binding site model even in the septic animal. Also, Bmax values and dissociation constants (Kds) were obtained by this analysis. The difference in the values obtained for the various groups were statistically compared. ${ }^{20}$

\section{Statistical analysis}

All data were presented as the arithmetic means \pm SEM. Following the confirmation of equal variance among the groups by the Bartlett test, ANOVA was carried out for multiple comparisons. Scheffe's method was used for comparison of means. Statistical significance was set at $P<0.05$. All statistical analyses were performed using the Software StatView 4.02 (Abacus concepts, Berkeley, CA).
TABLE I Physiological variables in the three groups

\begin{tabular}{lccc}
\hline & $\begin{array}{l}\text { Contmol } \\
(n=6)\end{array}$ & $\begin{array}{l}\text { Sham- } \\
\text { operated } \\
(n=6)\end{array}$ & $\begin{array}{l}\text { CLP model } \\
(n=6)\end{array}$ \\
\hline Blood pressure $(\mathrm{mmHg})$ & $128 \pm 6$ & $125 \pm 5$ & $90 \pm 4^{*}$ \\
- Systolic & $74 \pm 2$ & $72 \pm 2$ & $63 \pm 4^{*}$ \\
- Diastolic & $352 \pm 8$ & $355 \pm 4$ & $395 \pm 7^{*}$ \\
Heart rate (beat $\left.\cdot \mathrm{min}^{-1}\right)$ & & & \\
Blood gas analysis & $7.44 \pm 0.02$ & $7.43 \pm 0.02$ & $7.50 \pm 0.02^{*}$ \\
- pH & $37 \pm 2$ & $36 \pm 2$ & $32 \pm 2^{*}$ \\
- PaCO $(\mathrm{mmHg})$ & $128 \pm 3$ & $128 \pm 4$ & $122 \pm 3$ \\
- PaO $(\mathrm{mmHg})$ & $191 \pm 14$ & $192 \pm 15$ & $200 \pm 15$ \\
Plasma glucose $\left(\mathrm{mg} \cdot \mathrm{dl}^{-1}\right)$ & & & \\
Plasma catecholamines & & & \\
- Epinephrine $\left(\mathrm{ng} \cdot \mathrm{ml}^{-1}\right)$ & $2.5 \pm 0.5$ & $2.8 \pm 0.6$ & $5.4 \pm 0.8^{*}$ \\
- Norepinephrine $\left(\mathrm{ng}^{\prime} \mathrm{ml}^{-1}\right)$ & $0.9 \pm 0.3$ & $1.3 \pm 0.3$ & $5.0 \pm 0.8^{*}$ \\
\hline
\end{tabular}

The physiological variables in the three groups were measured at $24 \mathrm{hr}$ after treatment. Values are the means I SEM. CLP: caecal ligation and puncture.

${ }^{*} P<0.05$ compared with control values.

\section{Results}

\section{Physiological and biochemical studies}

At $24 \mathrm{hr}$ after treatment, the blood pressure (systolic and diastolic) was lower in the CLP group than in the control and sham-operated groups $(P<0.05)$, and heart rate was greater in the CLP group than in the other two groups $(P<0.05)$. The plasma catecholamine concentration (epinephrine and norepinephrine) was higher in the CLP group than in the other two groups $(P<0.05)$. The pH was higher and $\mathrm{PaCO}_{2}$ was lower in the CLP group than the other two groups $(P<0.05)$. There were no differences in plasma glucose concentrations (Table I).

The concentration of aromatic amino acids (phenylalanine, tryptophan and tyrosine) was higher in the CLP group than in the control and sham-operated groups ( $P$ $<0.05$ ). The concentration of branched chain amino acids (BCAA; isoleucine, leucine and valine) was lower in the CLP group than in the other two groups $(P<$ 0.05 ). The concentration of sulphur-containing amino acids (cysteine, methionine and taurine) was elevated in the CLP group $(P<0.05)$ (Table II).

The plasma endotoxin concentration $24 \mathrm{hr}$ after treatment was higher in the caecal ligation and puncture (CLP) group than in the other two groups (control; 17.1 \pm 4.2 , sham-operated; $19.1 \pm 4.5$, CLP; $432 \pm 39)(P$ $<0.05$ ), (Figure 1).

Benzodiazepine receptor binding studies

Figure 2 shows typical Scatchard plots for $\left[{ }^{3} \mathrm{H}\right]$ diazepine 
TABLE II Plasma amino acid concentrations in the three groups

\begin{tabular}{lccc}
\hline $\begin{array}{l}\text { Amino acid } \\
\left(n m o l \cdot m^{-1}\right)\end{array}$ & $\begin{array}{l}\text { Control } \\
(n=6)\end{array}$ & $\begin{array}{l}\text { Sham-operated } \\
(n=6)\end{array}$ & $\begin{array}{l}\text { CLP model } \\
(n=6)\end{array}$ \\
\hline $\begin{array}{l}\text { Phenylalanine } \\
\text { Tryptophan }\end{array}$ & $78.2 \pm 1.3$ & $77.4 \pm 2.7$ & $87.4 \pm 4.2^{*}$ \\
Tyrosine & $65.3 \pm 2.4$ & $61.6 \pm 2.3$ & $93.1 \pm 1.5^{*}$ \\
& $65.8 \pm 3.1$ & $71.2 \pm 3.1$ & $91.2 \pm 2.6^{*}$ \\
Isoleucine & $118.5 \pm 2.6$ & $132.8 \pm 3.8$ & $98.3 \pm 1.3^{*}$ \\
Leucine & $225.1 \pm 3.1$ & $226.3 \pm 3.8$ & $174.5 \pm 7.8^{*}$ \\
Valine & $260.9 \pm 5.1$ & $241.3 \pm 8.8$ & $196.7 \pm 4.5^{*}$ \\
& & & \\
Cysteine & $3.6 \pm 0.5$ & $3.7 \pm 0.4$ & $8.7 \pm 0.4^{*}$ \\
Methionine & $40.8 \pm 2.9$ & $56.2 \pm 2.5$ & $69.8 \pm 2.3^{*}$ \\
Taurine & $231.8 \pm 10.1$ & $260.3 \pm 19.6$ & $502.3 \pm 21.3^{*}$ \\
\hline
\end{tabular}

The plasma amino acid concentrations in the three groups were measured at $24 \mathrm{hr}$ after treatment. Values are the means \pm SEM. CLP: caecal ligation and puncture.

$* P<0.05$ compared with control values.

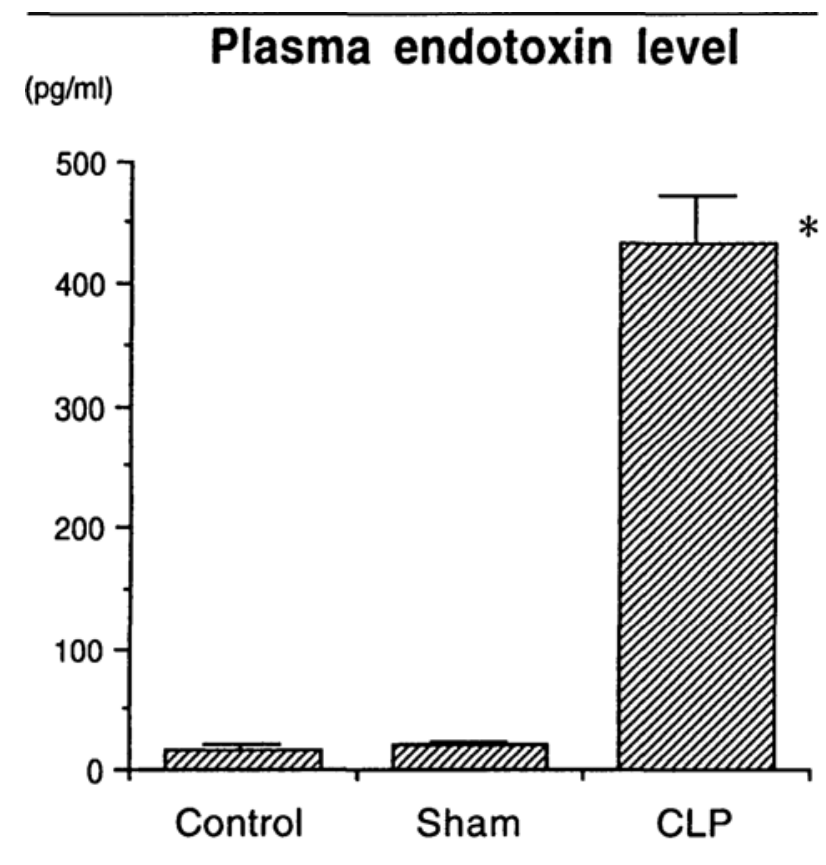

FIGURE 1 Plasma endotoxin conoentration $24 \mathrm{hr}$ after treatment. Values are the means $\pm S E M .{ }^{*} P<0.05$ compared with control group.

binding to synaptic membrane preparations from the forebrain, cerebellum and brain stem. There were no differences in the dissociation constant (Kd value) for the three groups in all regions examined (forebrain, cerebellum and brain stem) (Table III). In all regions, the maximum number of binding sites (Bmax value) was elevated in the CLP group $(P<0.05)$ (Table IV).

\section{Discussion}

The septic shock state in the caecal ligation and puncture (CLP) model

The animal model of caecal ligation and puncture was prepared as described by Wichterman et al. ${ }^{9}$ The physiological signs at $24 \mathrm{hr}$ after the operation showed that the heart rate had increased and the blood pressure had decreased in the caecal ligation and puncture group, indicating that this group was in a state of shock. The plasma endotoxin concentration in the CLP group was higher than in the other two groups. The plasma catecholamine concentration in the CLP group was elevated at $24 \mathrm{hr}$ after operation, and the values observed were consistent with previous reports. ${ }^{21,22}$ Although the high concentration of endotoxin itself is not necessarily the cause of septic shock or the resulting high mortality, ${ }^{23}$ these observations indicate that the CLP model rats in this study were in a state of septic shock induced by severe bacterial infection at $24 \mathrm{hr}$ after the operation. The plasma endotoxin concentration is reported to be increased in gram-negative and gram-positive infections. ${ }^{24}$ In view of the fact that we used the caecal ligation and puncture model, it is probable that the shock state was induced by a gram-negative bacterial infection. ${ }^{9}$

\section{The alteration in the plasma amino acids}

In this study, we observed alterations in the plasma amino acid profile in the septic model rat. These changes were a decrease in the concentration of branched chain amino acids (BCAA), and an increase in the concentrations of aromatic acids and sulphur-containing amino acids. The result was compatible with previous reports. ${ }^{4,14,25-28}$ The reduction in the level of branched chain amino acids probably reflects the increased oxidation of these amino acids in septic muscle and fat. ${ }^{14,28}$ Jeppsson et al. suggested that an alteration in the plasma amino acid profile may alter the profile of amino acids found in the brain, because blood-brain barrier transport of neutral amino acids was increased in septic rats. ${ }^{26}$ Under these circumstances, it may be that the concentrations of brain neurotransmitter is disturbed and their receptors are altered. Thus, it may be that the neural function of the septic rat might be affected by the alteration of the amino acid profile observed in this experiment. ${ }^{25}$

\section{The alteration in benzodiazepine receptor density in the brain}

We found that the number of benzodiazepine receptors was increased in all regions (forebrain, cerebellum and brain stem) of the CLP rat brain. This alteration might be the principle cause of the supersensitivity to benzo- 

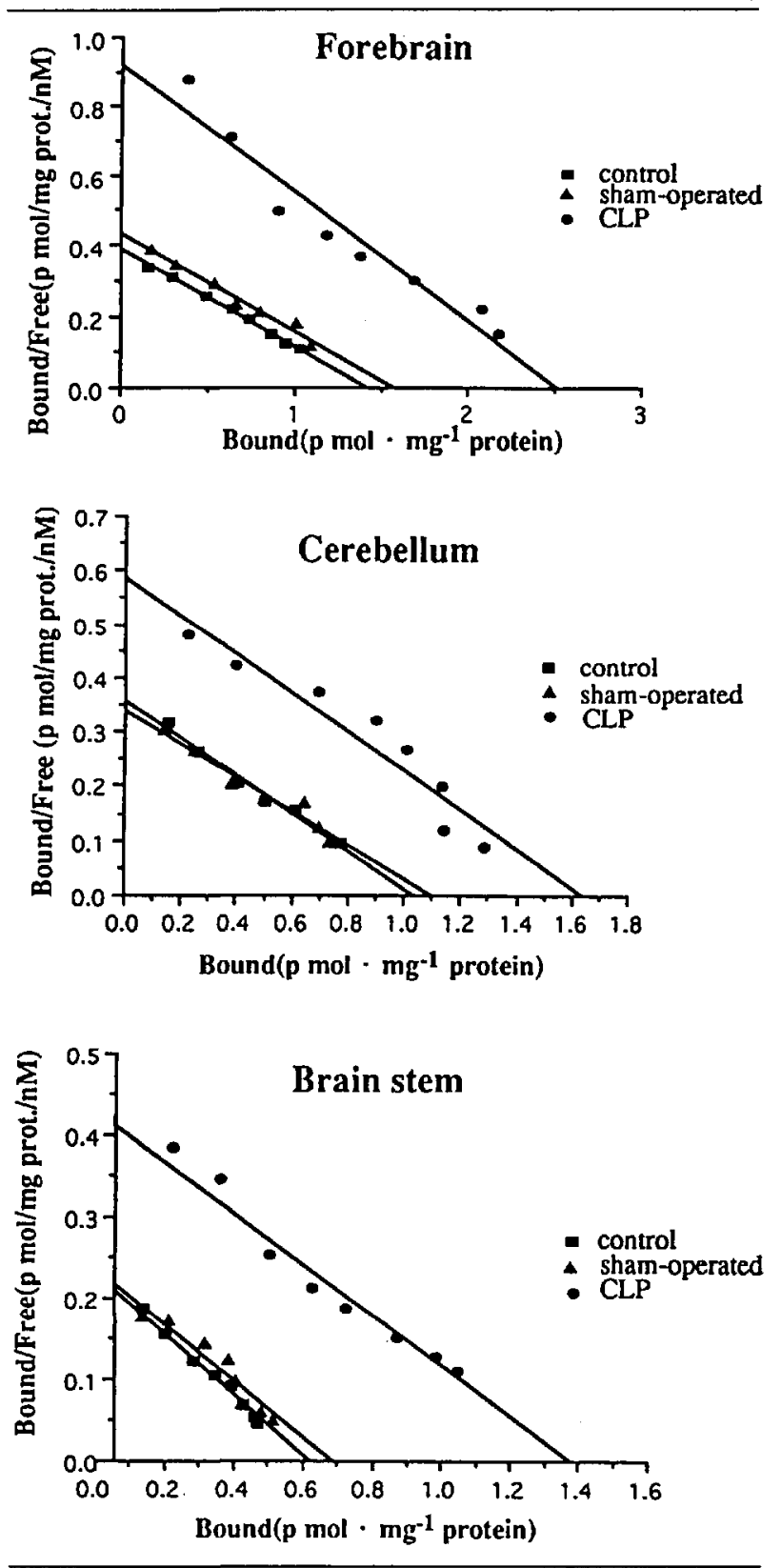

FIGURE 2 Typical Scatchard plot analyses of $\left[{ }^{3} \mathrm{H}\right]$ diazepam binding to synaptic membrane preparations of the forebrain, cerebellum and brain stem.

diazepine observed in the CLP model used in this study. There are several reports describing the increase in benzodiazepine receptor density in other pathological situations. ${ }^{8,29-31}$ Baraldi et al. reported that benzodiazepine receptor density increased in hepatic encephalopathy due to fulminant hepatic failure induced by galactosamine. ${ }^{8}$ Motohashi et al. described that acute swim stress increased the number of benzodiazepine receptors in the
TABLE III The dissociation constant (Kd value) in the three groups (nM) (benzodiazepine receptor)

\begin{tabular}{llll}
\hline & $\begin{array}{l}\text { Control } \\
(n=8)\end{array}$ & $\begin{array}{l}\text { Sham-operated } \\
(n=8)\end{array}$ & $\begin{array}{l}\text { CLP model } \\
(n=8)\end{array}$ \\
\hline Forebrain & $3.14 \pm 0.01$ & $3.07 \pm 0.12$ & $3.13 \pm 0.12$. \\
Cerebellum & $2.98 \pm 0.03$ & $3.00 \pm 0.10$ & $3.02 \pm 0.07$ \\
Brain stem & $2.91 \pm 0.06$ & $2.94 \pm 0.06$ & $2.99 \pm 0.08$ \\
\hline
\end{tabular}

There were no differences in dissociation constants (Kd value) of the three groups. Values are the means \pm SEM.

TABLE IV The maximum number of binding sites (Bmax value) in the three groups (pmol $\cdot \mathrm{mg}^{-1}$ protein) (benzodiazepine receptor)

\begin{tabular}{llll}
\hline & $\begin{array}{l}\text { Control } \\
(n=8)\end{array}$ & $\begin{array}{l}\text { Sham-operated } \\
(n=8)\end{array}$ & $\begin{array}{l}\text { CLP model } \\
(n=8)\end{array}$ \\
\hline Forebrain & $1.45 \pm 0.02$ & $1.49 \pm 0.03$ & $2.37 \pm 0.04^{*}$ \\
Cerebellum & $1.05 \pm 0.02$ & $1.09 \pm 0.02$ & $1.55 \pm 0.05^{*}$ \\
Brain stem & $0.61 \pm 0.02$ & $0.63 \pm 0.02$ & $1.21 \pm 0.04^{*}$ \\
\hline
\end{tabular}

$\left[{ }^{3} \mathrm{H}\right]$ diazepam binding to the synaptic membranes was determined for the three groups. Values are the means \pm SEM.

$* P<0.05$ compared with control values.

rat cerebral cortex and that cortical benzodiazepine receptors might be closely related to responses to acute stress. ${ }^{29}$ In these cases, the molecular mechanism of receptor alteration was not fully understood. Recent molecular neurobiochemical observations have suggested that one type of neurotransmission system controls another type of neurotransmission system via a "receptor cross-talk mechanism," which is known to utilize protein kinases as modulators. ${ }^{32,33}$ Several reports have indicated that septic shock is associated with an altered brain neurotransmitter profile, including the activation of the inhibitory serotoninergic neurotransmission system and the reduction of catecholamine neurotransmission tone. ${ }^{5,6,34-36}$ Therefore, the changes in the benzodiazepine receptor detected in our study might be induced by a cross-talk mechanism with other transmission systems, such as the serotoninergic and catecholaminergic systems. Further investigation is necessary to clarify the underlying molecular mechanisms causing the alteration in the benzodiazepine receptor in septic animals.

In this study, we demonstrated that the benzodiazepine receptor density was increased in a septic shock animal model. It is unclear whether the results of these animal experiments may be extrapolated to include humans. However, if the agitation and delirium which occur in septic shock patients are due to increased benzodiazepine receptors, it should be questioned whether it is appropriate to treat patients with septic encephalopathy with drugs that effect benzodiazepine receptors. 


\section{Acknowledgements}

The authors thank Miss T. Kakinuma for her technical assistance, and also thank Dr. Elizabeth Kamei for her assistance in English editing.

\section{References}

1 Rall TW. Hypnotics and sedatives; ethanol. In: Gilman AG, Rall TW, Nies AS, Taylor P (Eds.). The Pharmacological Basis of Therapeutics, 3rd ed. New York: Pergamon Press Inc., 1990; 345-82.

2 Reves JG, Glass PSA, Lubarsky DA. Nonbarbiturate intravenous anesthetics. In: Miller RD (Ed.). Anesthesia, 4th ed. New York: Churchill Livingstone Inc., 1994; 247-89.

3 Freund HR, Ryan JA Jr, Fischer JE. Amino acid derangements in patients with sepsis: treatment with branched chain amino acid rich infusions. Ann Surg 1978; 188: 423-30.

4 Freund HR, Atamian S, Holroyde J, Fischer JE. Plasma amino acids as predictors of the severity and outcome of sepsis. Ann Surg 1979; 190: 571-6.

5 Bowton DL. CNS effects of sepsis. Crit Care Clin 1989; 5: 785-92.

6 Hasselgren $P-O$, Fischer JE. Septic encephalopathy. Etiology and management. Intensive Care Med 1986; 12: 13-6.

7 Sprung CL, Cerra FB, Freund HR, et al. Amino acid alterations and encephalopathy in the sepsis syndrome. Crit Care Med 1991; 19: 753-7.

8 Baraldi $M$, Zeneroli $M L$, Ventura $E$, et al. Supersensitivity of benzodiazepine receptors in hepatic encephalopathy due to fulminant hepatic failure in the rat: reversal by a benzodiazepine antagonist. Clin Sci 1984; 67: 167-75.

9 Wichterman KA, Baue AE, Chaudry IH. Sepsis and septic shock - a review of laboratory models and a proposal. $\mathbf{J}$ Surg Res 1980; 29: 189-201.

10 Felice LJ, Felice JD, Kissinger PT. Determination of catecholamines in rat brain parts by reverse-phase ion-pair liquid chromatography. J Neurochem 1978; 31: 1461-5.

11 Umegae $Y$, Nohta $H$, Lee $M$, Ohkura Y. 1,2-diarylethylenediamines as pre-column fluorescence derivatization reagents in high-performance liquid chromatographic determination of catecholamines in urine and plasma. Chem Pharm Bull 1990; 38: 2293-5.

12 Fink PC, Lehr L, Urbaschek RM, Kozak J. Limulus amebocyte lysate test for endotoxemia: investigations with a femtogram sensitive spectrophotometric assay. Klinische Wochenschrift 1981; 59: 213-8.

13 Ikeda T, Hirata K, Tabuchi K, Tamura H, Tanaka S. Quantitative measurement of endotoxin in canine plasma using the new endotoxin-specific chromogenic test. Circ Shock 1987; 23: 263-9.

14 Mizock BA. Branched-chain amino acids in sepsis and hepatic failure. Arch Intern Med 1985; 145: 1284-8.
15 Uhe AM, Collier GR, McLennan EA, Tucker DJ, O'Dea $K$. Quantitation of tryptophan and other plasmic amino acids by automated pre-column o-phthaldialdehide derivatization high-performance liquid chromatography: improved sample preparation. J Chromatogr 1991; 564: 81-91.

16 Glowinski J, Iversen $L L$. Regional studies of catecholamines in the rat brain-1. The disposition of $\left[{ }^{3} \mathrm{H}\right]$ norepinephrine, $\left[{ }^{3} \mathrm{H}\right]$ dopamine and $\left[{ }^{3} \mathrm{H}\right]$ dopa in various regions of the brain. J Neurochem 1966; 13: 655-69.

17 Möhler H, Okada T. Properties of ${ }^{3} \mathrm{H}$-diazepam binding to benzodiazepine receptors in rat cerebral cortex. Life Sci 1977; 20: 2101-10.

18 Bradford MM. A rapid and sensitive method for the quantitation of microgram quantities of protein utilizing the principle of protein-dye binding. Anal Biochem 1976; 72: 248-54.

19 Zeneroli $M L$, Baraldi $M$, Ventura $E$, et al. Alterations of GABA-A and dopamine D-2 brain receptors in dogs with portal-systemic encephalopathy. Life Sci 1991; 48: 37-50.

20 Bylund DB, Yamamura HI. Methods for receptor binding. In: Yamamura HI, Enna SJ, Kuhar MJ (Eds.). Methods in Neurotransmitter Receptor Analysis. New York: Raven Press, Ltd., 1990: 1-36.

21 Kovarik $M F$, Jones $S B$, Romano FD. Plasma catecholamines following cecal ligation and puncture in the rat. Circ Shock 1987; 22: 281-90.

22 Schlag G, Redl H. Pathophysiology of Shock, Sepsis, and Organ Failure. Berlin: Springer-Verlag, 1993.

23 Parrilo JE, Parker MM, Natanson C, et al. Septic shock in humans. Advances in the understanding of pathogenesis, cardiovascular dysfunction, and therapy. Ann Intern Med 1990; 113: 227-42.

24 Casey LC, Balk RA, Bone RC. Plasma cytokine and endotoxin levels correlate with survival in patients with the sepsis syndrome. Ann Intern Med 1993; 119: 771-8.

25 Smith $A R$, Rassi-Fanelli $F$, Zipaco $V$, et al. Alterations in plasma and CSF amino acids, amines and metabolites in hepatic coma. Ann Surg 1977; 187: 343-50.

26 Jeppsson B, Freund HR, Gimmon Z, James JH, von Meyenfeldt $M F$, Fischer JE. Blood-brain barrier derangement in sepsis: cause of septic encephalopathy? Am J Surg 1981; 141: 136-42.

27 Vente JP, von Meyenfeldt MF, Van Eijk HMH, et al. Plasma-amino acid profiles in sepsis and stress. Ann Surg 1989; 209: 57-62.

28 Takezawa J, Taenaka N, Nishijima MK, et al. Amino acids and thiobarbituric acid reactive substances in cerebrospinal fluid and plasma of patients with septic encephalopathy. Crit Care Med 1983; 11: 876-9.

29 Motohashi N, Okamoto Y, Osada M, Yamawaki S. Acute swim stress increases benzodiazepine receptors, but not $\mathrm{GABA}_{A}$ and $\mathrm{GABA}_{\mathrm{B}}$ receptors, in the rat cerebral cortex. Neurochem Int 1993; 23: 327-30. 
30 Havoundjian H, Paul SM, Skolnick P. Rapid, stressinduced modification of the benzodiazepine receptorcoupled chloride ionophore. Brain Res 1986; 375: 401-6.

31 Lai $H$, Carino $M A$. Acute white noise exposure affects the concentration of benzodiazepine receptors in the brain of the rat. Pharmacol Biochem Behav 1990; 36: 985-7.

32 Sibley $D R$, Lefkowitz RJ. Molecular mechanisms of receptor desensitization using the $\beta$-adrenergic receptorcoupled adenylate cyclase system as a model. Nature 1985; 317: 124-8.

33 Wightman PD, Raetz CRH. The activation of protein kinase $C$ by biologically active lipid moieties of lipopolysaccharide: J Biol Chem 1984; 259: 10048-52.

34 Freund HR, Muggia-Sullam M, Peiser J, Melamed E. Brain neurotransmitter profile is deranged during sepsis and septic encephalopathy in the rat. J Surg Res 1985; 38: 267-71.

35 Dunn AJ. Endotoxin-induced activation of cerebral catecholamine and serotonin metabolism: comparison with interleukin-1. J Pharm Exp Ther 1992; 261: 964-9.

36 Kabiersch A, Rey AD, Honegger CG, Besedovsky HO. Interleukin-1 induces changes in norepinephrine metabolism in the rat brain. Brain Behav Immun 1988; 2: 267-74. 